\title{
The Effect of Delaware Doctrine on Freezeout Structure \& Outcomes: Evidence on the Unified Approach
}

\section{Citation}

Fernán Restrepo \& Guhan Subramanian, The Effect of Delaware Doctrine on Freezeout Structure \& Outcomes: Evidence on the Unified Approach, 5 Harv. Bus. L. Rev. 205 (2015).

\section{Published Version}

http://www.hblr.org/wp-content/uploads/2015/06/HBLR-5.2.-Restrepo-Subramanian-the-Effectof-Delaware-Doctrine.pdf

\section{Permanent link}

http://nrs.harvard.edu/urn-3:HUL.InstRepos:17326756

\section{Terms of Use}

This article was downloaded from Harvard University's DASH repository, and is made available under the terms and conditions applicable to Other Posted Material, as set forth at http:// nrs.harvard.edu/urn-3:HUL.InstRepos:dash.current.terms-of-use\#LAA

\section{Share Your Story}

The Harvard community has made this article openly available.

Please share how this access benefits you. Submit a story.

\section{Accessibility}




\title{
THE EFFECT OF DELAWARE DOCTRINE ON FREEZEOUT STRUCTURE \& OUTCOMES: EVIDENCE ON THE UNIFIED APPROACH
}

\author{
FERNÁN RESTREPO* \\ GuHan Subramanian**
}

\begin{abstract}
Historically, Delaware corporate law provided different standards of judicial review for buyouts by controlling shareholders (also known as "freezeouts"). The standards were based on what transactional form was used: deferential business judgment review for freezeouts executed as tender offers and stringent "entire fairness" review for transactions structured as mergers. Subramanian (2005), Subramanian (2007), and Restrepo (2013) provide doctrinal and empirical evidence that (1) transactional planners responded to these differences in standards of judicial review; (2) these differences in judicial scrutiny created differences in outcomes for the minority shareholders; and (3) differences in outcomes created a social welfare loss, not just a wealth transfer from minority shareholders to the controlling shareholder. Over the past decade, in a series of important decisions, Delaware law has migrated toward a unified approach to freezeouts regardless of transactional form. In this Article we present empirical evidence on all freezeouts of Delaware targets during this period of doctrinal evolution. In general, we find that deal outcomes converged after the Delaware Chancery Court's decision in In re Cox Communications, Inc. Shareholders Litigation. Our findings suggest that: (1) transactional planners seem to respond to even dicta in the Delaware case law; and (2) the social welfare loss identified in Subramanian (2005) seems no longer to be present. This result in turn suggests that the Delaware Supreme Court seems to have adopted the correct policy by endorsing the unified approach for merger freezeouts in Kahn v. M\&F Worldwide Corp., and moreover, that the court should also explicitly endorse this approach in the context of tender offer freezeouts when presented with such facts.
\end{abstract}

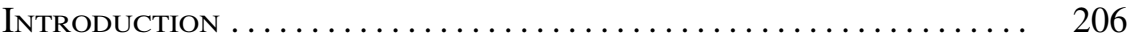

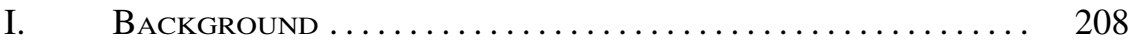

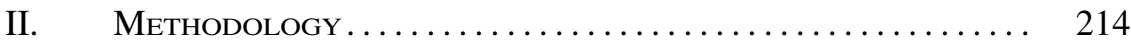

III. Results ...................................... 217

A. Descriptive Statistics .................... 217

B. Multivariate Analysis ........................ 219

1. Baseline Specification ..................... 219

2. Alternative Specifications ............... 219

3. Deal Incidence Analysis ................... 222

IV. Discussion ............................... 222

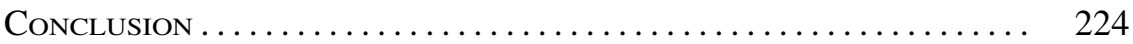

* Stanford Law School. Email address: fernanr@stanford.edu.

** Harvard Law School and Harvard Business School. Email address: gsubramanian@hbs.edu.

The authors thank Michael Klausner, George Triantis, and seminar participants at Harvard Law School for comments, and Emily Cole (Harvard Law School Class of 2015) and Sidhant Misra (Harvard College Class of 2014) for outstanding research assistance. Fernán Restrepo also thanks the John M. Olin Program in Law and Economics at Stanford Law School for financial support. 
Historically, buyouts by controlling shareholders (also known as "going-private transactions," "squeeze outs," and, hereinafter, "freezeouts") were subject to different standards of judicial scrutiny under Delaware corporate law based on the transactional form used by the controlling shareholder to execute the deal. In a line of cases dating back at least to the Delaware Supreme Court's 1994 decision in Kahn v. Lynch Communication Systems, Inc., ${ }^{1}$ a freezeout executed as a statutory merger was subject to stringent "entire fairness" review due to the self-dealing nature of the transaction. In contrast, in a line of cases beginning with the Delaware Chancery Court's 2001 opinion in In re Siliconix Inc. Shareholders Litigation, ${ }^{2}$ a freezeout executed as a tender offer was subject to deferential business judgment review.

Subramanian presents evidence that, after Siliconix, minority shareholders received less in tender offer freezeouts than in merger freezeouts. ${ }^{3}$ Restrepo finds that these differences in outcomes occurred only after Siliconix, and that the incidence of tender offer freezeouts increased after this opinion, supporting the idea that controlling shareholders took advantage of the opportunity provided by Siliconix. ${ }^{4}$ Subramanian describes why these differences in outcomes for minority shareholders create a social welfare loss and not just a one-time wealth transfer from minority shareholders to the controlling shareholder. ${ }^{5}$ This Article work is a continuation of this line of research, which offers, in particular, a different perspective from which to examine the effect of different standards of judicial review on the gains of the minority shareholders.

In In re Cox Communications, Inc. Shareholders Litigation, ${ }^{6}$ then-Vice Chancellor Strine, citing empirical evidence presented in the working paper version of Subramanian ${ }^{7}$ as well as other academic commentary, proposed in dicta a unified approach that would govern freezeout transactions. This approach entailed business judgment review for freezeouts that are approved by a special committee of independent directors and by a majority-of-the-

\footnotetext{
${ }^{1}$ Kahn v. Lynch Commc'n Sys., Inc., 638 A.2d 1110, 1115 (Del. 1994).

${ }^{2}$ In re Siliconix Inc. S'holders Litig., No. 18700, 2001 WL 716787, at *6 (Del. Ch. June 19, 2001).

${ }^{3}$ Guhan Subramanian, Post-Siliconix Freezeouts: Theory and Evidence, 36 J. LegaL STUD. 1,1 (2007).

${ }^{4}$ Fernán Restrepo, Do Different Standards of Judicial Review Affect the Gains of Minority Shareholders in Freeze-Out Transactions? A Re-examination of Siliconix, 3 Harv. Bus. L. REv. 321, 321 (2013).

${ }^{5}$ Guhan Subramanian, Fixing Freezeouts, 115 Yale L.J. 2, 30 (2005).

${ }^{6}$ In re Cox Commc'ns, Inc. S'holders Litig., 879 A.2d 604, 625-37 (Del. Ch. 2005). For ease of reference, we refer to In re Cox Communications as Cox in this Article. This case is distinguished from another case we discuss, In re Cox Radio, Inc. S'holders Litig., No. 4461VCP, 2010 WL 1806616 (Del. Ch. May 6, 2010).

${ }^{7}$ Guhan Subramanian, Post-Siliconix Freeze-Outs: Theory and Evidence 19 (Harvard Law School, Olin Series Discussion Paper No. 472, Aug. 2004).
} 
minority shares (regardless of the transactional form used by the controller) and entire fairness review for freezeouts that do not have these procedural protections. Subsequent decisions by the Delaware Chancery Court have both accepted (for example, In re John Q. Hammons Hotels Inc. Shareholder Litigation, ${ }^{8}$ In re CNX Gas Corp. Shareholders Litigation, ${ }^{9}$ and In re MFW Shareholders Litigation ${ }^{10}$ ) and implicitly rejected (for example, In re Cox Radio, Inc. Shareholders Litigation ${ }^{11}$ ) this unified approach. More recently, in Kahn v. M\&F Worldwide Corp. ${ }^{12}$ the Delaware Supreme Court endorsed this approach in the context of a merger freezeout.

There is no empirical evidence, however, on whether or not the outcome differences identified by Subramanian ${ }^{13}$ and Restrepo ${ }^{14}$ persisted after Cox, and, therefore, on the effect that the unified approach proposed in that decision has had on the gains of minority shareholders. The purpose of this Article is to fill this gap in the literature. To this end, we construct a new sample of all freezeouts of Delaware targets announced between Siliconix and $\operatorname{Cox}(\mathrm{n}=79)$ and between Cox and the Delaware Chancery Court opinion in $M F W(\mathrm{n}=66)$. We find that: (1) the differences in outcomes during the pre-Cox era identified by Subramanian ${ }^{15}$ and Restrepo ${ }^{16}$ have disappeared since Cox; (2) the number of freezeout tender offers has declined since Cox, consistent with practitioner intuition that the unified approach proposed in that decision reduced the benefits of the freezeout tender offer form relative to the freezeout merger form; and (3) while the number of majority-of-theminority ("MOM") conditions has increased since Cox, consistent with the intuition that more deals are attempting to fit into the unified approach blueprint, approximately half of merger freezeouts did not include MOM conditions.

Taken together, these findings suggest that: (1) transactional planners seem to respond to even dicta in Delaware case law regarding standards of judicial review; and (2) the social welfare loss identified by Subramanian ${ }^{17}$ seems no longer to be present in the post-Cox era. This result in turn suggests that the Delaware Supreme Court seems to have adopted the correct policy by endorsing the unified approach for merger freezeouts in Kahn $v$. $M \& F$ Worldwide Corp.,$^{18}$ and moreover, that the court should also explicitly

${ }^{8}$ In re John Q. Hammons Hotels Inc. S'holder Litig., No. 758-CC, 2009 WL 3165613 (Del. Ch. Oct. 2, 2009).

${ }^{9}$ In re CNX Gas Corp. S'holders Litig., 4 A.3d 397 (Del. Ch. 2010).

${ }^{10}$ In re MFW S'holders Litig., 67 A.3d 496 (Del. Ch. 2013).

${ }^{11}$ In re Cox Radio, Inc. S'holders Litig., No. 4461-VCP, 2010 WL 1806616 (Del. Ch. May 6, 2010).

${ }^{12}$ Kahn v. M\&F Worldwide Corp., 88 A.3d 635, 653 (Del. 2014).

${ }^{13}$ Subramanian, supra note 3.

${ }^{14}$ Restrepo, supra note 4.

${ }^{15}$ Subramanian, supra note 3.

${ }^{16}$ Restrepo, supra note 4.

${ }^{17}$ Subramanian, supra note 5, at 34-38.

${ }^{18}$ Kahn v. M\&F Worldwide Corp., 88 A.3d 635, 644 (Del. 2014). 
endorse that approach in the context of tender offer freezeouts when presented with such facts.

The remainder of this Article proceeds as follows. Part I presents background on freezeout doctrine, beginning with the Delaware Supreme Court's 1983 decision in Weinberger v. UOP ${ }^{19}$ and continuing through to the Delaware Supreme Court's 2014 decision in Kahn v. M\&F Worldwide Corp. ${ }^{20}$ Part II presents our methodology. Part III presents our empirical results. Part IV discusses the implications of our findings for Delaware courts and for transactional planners.

\section{BACKGROUND}

A freezeout (also known, with some occasional loss of precision, as a "going-private merger," a "squeeze-out," a "parent-subsidiary merger," a "minority buyout," a "take-out," or a "cash-out merger") is a transaction in which a controlling shareholder buys out the minority shareholders for cash or the controller's stock. ${ }^{21}$ Freezeouts can be executed basically in two ways: as a merger or as a tender offer. In the more traditional merger route, following the process described in Weinberger v. UOP ${ }^{22}$ and Kahn v. Lynch, ${ }^{23}$ the target board typically establishes a special committee of independent directors to negotiate the terms of the deal with the controller, and if an agreement is reached, the transaction is submitted for the necessary board and shareholder approvals. If approved, the deal is usually executed as a statutory merger or as a two-step tender offer (a first-step tender offer followed by a short-form merger), although it can also be executed as a reverse stock split or as an asset acquisition.

In the tender offer route, the controlling shareholder goes directly to the minority shareholders and usually conditions the transaction on obtaining $90 \%$ voting control (a "90\% condition"). This condition is explained by the fact that the $90 \%$ threshold gives the controller a right to execute a shortform merger (which, under Delaware law, does not require a shareholder vote) in order to eliminate the remaining (non-tendering) minority investors. Similar to the merger route, in tender offers the target board typically appoints a special committee of independent directors to negotiate with the controller. Once the negotiation stage is completed, the special committee must issue a 14D-9 recommendation to the minority shareholders in the form

${ }^{19}$ Weinberger v. UOP, Inc., 457 A.2d 701 (Del. 1983).

${ }^{20} M \& F$ Worldwide Corp., 88 A.3d at 635.

${ }^{21}$ The first half of this Part, through the paragraphs discussing Siliconix and Glassman, is based in large part on the background portion of Post-Siliconix Freezeouts: Theory and Evidence, previously published by Subramanian in the Journal of Legal Studies. See Subramanian, supra note 3 , at $2-4$.

${ }^{22}$ Weinberger, 457 A.2d at 709 n.7.

${ }^{23}$ Kahn v. Lynch Commc'n Sys., Inc., 638 A.2d 1110, 1110 (Del. 1994). 
of one of following options: approve, reject, neutral, or unable to take a position.

Freezouts involve an element of self-dealing because the controller is the buyer and typically dominates the seller's board. As a result, the Delaware courts generally subject these transactions to a stringent "entire fairness" standard of review. Before the $M F W$ cases in 2013 and 2014,,$^{24}$ even procedural protections such as the use of a special committee or a MOM condition only served to shift the burden of proof on entire fairness to the plaintiff. ${ }^{25}$ In the particular case of tender offers, however, the Delaware Chancery Court held in In re Siliconix Inc. Shareholders Litigation that entire fairness review does not apply to this transactional form "unless actual coercion or disclosure violations are shown," 26 because the tender decision is supposed to be a sufficient protection for the minority shareholders and Delaware statutory law does not provide a role for the target board in tender offers. Moreover, just one month after Siliconix, the Delaware Supreme Court held in Glassman v. Unocal Exploration Corp. ${ }^{27}$ that a short-form merger is also exempted from entire fairness review. Taken together, therefore, Siliconix and Glassman enabled a controlling shareholder to avoid entire fairness review by executing its freezeout as a tender offer followed by a short-form merger. This result in turn created a doctrinal discrepancy in terms of standards of judicial review for two transactional forms that achieve identical economic results (that is, the elimination of the minority shareholders). ${ }^{28}$

${ }^{24}$ See infra notes 43, 45.

${ }^{25}$ See Lynch Commc'n Sys., Inc., 638 A.2d at 1110; Rosenblatt v. Getty Oil, 493 A.2d 929, 937 (Del. 1985).

${ }^{26}$ In re Siliconix Inc. S'holders Litig., No. 18700, 2001 WL 716787, at *6 (Del. Ch. June $212001)$.

${ }^{27}$ Glassman v. Unocal Exploration Corp., 777 A.2d 242, 248 (Del. 2001).

${ }^{28}$ Some commentators argue that the result in Siliconix was dictated by the 1996 case Solomon v. Pathe Commc'ns, 672 A.2d 35 (Del. 1996). There, the Delaware Supreme Court held that a tender offer made by a controlling shareholder was not subject to entire fairness review. See Jon E. Abramczyk, Jason A. Cincilla \& James D. Honaker, Going-Private "Dilemma"? - Not in Delaware, 58 Bus. Law. 1351, 1354 (2003); see also Donald J. Wolfe, Jr., The Odd Couple: Majority of Minority Approval and the Tender Offer, M\&A LAWYER, Nov./ Dec. 2002, at 6. However, others have pointed out that Solomon was not a freezeout situation and, consequently, its result could have been limited to the case's particularized facts. See Ronald J. Gilson \& Jeffrey N. Gordon, Controlling Controlling Shareholders, 152 U. PenN. L. Rev. 785, 818 (2003). In addition, Aronstam, Balotti, and Rehbock suggest that the standard of review for the back-end short-form merger was only resolved by Glassman. See Bradley R. Aronstam, R. Franklin Balotti \& Timo Rehbock, Delaware's Going-Private Dilemma: Fostering Protections for Minority Shareholders in the Wake of Siliconix and Unocal Exploration, 58 Bus. Law. 519, 520 (2003). Moreover, as Vice Chancellor Laster held in CNX, Solomon did not involve a unilateral tender offer. The transaction was one of the components of a prior agreement between CLBN and Pathe, which was established when these companies negotiated the rights of CLBN as a secured creditor in the acquisition of MGM shares by Pathe. For the same reason, CLBN was acting in the deal predominantly as a third-party lender, not as a controlling shareholder-CLBN, although having a controlling position by the time of the tender offer, executed that offer in exercise and under the conditions of its contractual rights as a secured lender, and that particular position is not subject to fiduciary review. See In re CNX 
Following Siliconix and Glassman, the Delaware Chancery Court further specified the conditions to qualify for the Siliconix safe harbor. In particular, in In re Pure Resources, Inc., Shareholders Litigation, ${ }^{29}$ the court held that a tender offer is not coercive, and therefore the business judgment rule applies, only if (1) the offer is subject to a non-waivable MOM condition; (2) the controller promises to promptly consummate a short-form merger at the same price if it obtains more than $90 \%$ of the shares; and (3) the controller makes no "retributive threats" in its negotiations with the target's special committee. In elaborating these conditions, the court "admitted being troubled" by the distinction created by Siliconix,${ }^{30}$ but nonetheless confirmed that if the conditions are met, a freezeout tender offer has the benefit of the business judgment rule.

Apparently the conventional view among practitioners was that these doctrinal developments would have a significant impact on freezeout transactional forms and outcomes, specifically by increasing the use of the tender offer route and decreasing the gains of minority shareholders. For example, the Wall Street Journal suggested that Siliconix and Glassman "essentially permit those big holders to buy the minority investors out on the cheap." 31 Similarly, Corporate Control Alert reported that "[t]he current thinking on minority buyouts, many lawyers say, boils down to two words: tender offer." ${ }^{32}$ As noted above, even the Delaware Chancery Court anticipated these potential effects in Pure Resources. ${ }^{33}$

Examining all freezeouts of Delaware targets announced in the four years after Siliconix, Subramanian found that minority shareholders received less in freezeout tender offers relative to freezeout mergers, as measured by the cumulative abnormal returns for the stock of the target around the an-

Gas Corp. S'holders Litig., 4 A.3d 397, 409 (Del. Ch. 2010). The results presented in this Article, Subramanian's paper, and Restrepo's paper support the view that the Siliconix and Glassman combination created a new doctrinal contour. See Subramanian, supra note 3; Restrepo, supra note 4.

${ }^{29}$ In re Pure Res., Inc., S'holders Litig., 808 A.2d 421, 442 (Del. Ch. 2002).

${ }^{30}$ In the words of then-Vice Chancellor Strine, "I admit being troubled by the imbalance in Delaware law exposed by the Solomon/Lynch lines of cases. Under Solomon, the policy emphasis is on the right of buyers and sellers of stock to deal with each other freely, with only such judicial intervention as is necessary to ensure fair disclosure and to prevent structural coercion. The advantage of this emphasis is that it provides a relatively non-litigious way to effect going private transactions and relies upon minority stockholders to protect themselves. The cost of this approach is that it arguably exposes minority stockholders to the more subtle form of coercion that Lynch addresses and leaves them without adequate redress for unfairly timed and priced offers. The approach also minimizes the potential for the minority to get the best price, by arguably giving them only enough protection to keep them from being structurally coerced into accepting grossly insufficient bids but not necessarily merely inadequate ones." Id. at 443 .

${ }^{31}$ Robin Sidel, Takeover Targets Force Up Offers in "Minority Squeeze-Out" Deals, Wall St. J., May 10, 2002, at C3; see also David Marcus, From Theory to Practice, Corporate Control Alert, Nov. 2004, at 10 ("Most deal lawyers believe buyers pay less if they use the [tender offer] method . . ..").

${ }^{32}$ David Marcus, Cleaning Up Your Corporate Structure, Corporate Control Alert, Jul. 2003, at 20.

${ }^{33}$ See Pure Res. S'holders Litig., 808 A.2d at 443. 
nouncement of the offer. In addition, Subramanian found that the incidence of tender offer freezeouts increased relative to the merger route, therefore providing empirical support for the practitioner intuition that differences in judicial standards of review created different outcomes for the minority shareholders. ${ }^{34}$ In a follow-up study, Restrepo confirmed these results by analyzing a sample of pre and post-Siliconix transactions and applying a difference-in-differences methodology. ${ }^{35}$ As Subramanian suggested in a previous paper, these differences are not simply a one-time wealth transfer from minority shareholders to the controller-an idea based on the assumption that minority shareholders will simply pay less for a minority stake if they know that they can be frozen out later at a lower price. These differences, in fact, create a permanent social welfare loss that requires judicial intervention..$^{36}$

In $C o x,{ }^{37}$ citing empirical evidence provided in the working paper version of Subramanian ${ }^{38}$ as well as other academic commentary, Vice Chancellor (now Chief Justice of the Delaware Supreme Court) Leo Strine proposed in dicta a unified approach for freezeouts. ${ }^{39}$ Under this unified standard, a freezeout that was approved by a special committee of independent directors and was conditioned upon approval from a majority of the minority shares would receive business judgment review, regardless of the transactional form used by the controlling shareholder. Conversely, a freezeout that did not provide both of these procedural protections would be scrutinized under the entire fairness standard. This approach would track the approval process for arm's-length mergers: approval from disinterested directors (through a special committee), followed by approval from disinterested shareholders (through a majority-of-the-minority condition). Vice Chancellor Strine observed that this unified standard was not necessarily in tension with the Delaware Supreme Court's Kahn v. Lynch decision:

In Lynch, the argument that both special committee and an effective majority of the Minority Approval Condition should, as a tandem, justify invocation of the business judgment rule, was never presented. Therefore, it is arguable that the Supreme Court has never been asked to address the precise question that would be posed if a controller, from the inception of a transaction, made clear that its merger proposal was conditioned upon the use of both of these procedural protections . . . ${ }^{40}$

\footnotetext{
${ }^{34}$ Subramanian, supra note 3 , at 2.

${ }^{35}$ Restrepo, supra note 4, at 326.

${ }^{36}$ Subramanian, supra note 5 , at 7.

${ }^{37}$ In re Cox Commc'ns, Inc. S'holders Litig., 879 A.2d 604 (Del. Ch. 2005).

${ }^{38}$ Subramanian, supra note 7.

${ }^{39}$ Subramanian provided an affidavit in Cox on behalf of plaintiffs in that matter.

${ }^{40}$ In re Cox Commc'ns, 879 A.2d at 648.
} 
After Cox, Chancery Court judges have taken different approaches, and a conclusive doctrine has been reached only in the context of merger freezeouts. In In re John Q. Hammons Hotels Inc. Shareholder Litigation, ${ }^{41}$ in particular, Chancellor Chandler seemed to endorse the unified standard for the merger freezeout mechanism by holding that "the use of both structural protections [special committee approval and a MOM condition] results in the controller standing only on one side of the transaction-as the buyer-and renders entire fairness inapplicable." ${ }^{42}$ More recently, in In re $M F W$ Shareholders Litigation, ${ }^{43}$ Chancellor Strine squarely endorsed this approach, on the grounds that the unified standard "will provide a strong incentive for controlling shareholders to accord minority investors . . . a structure where stockholders get the benefits of independent, empowered negotiating agents to bargain for the best price ... plus the critical ability to determine for themselves whether to accept any deal that their negotiating agents recommend to them." ${ }^{44}$ On appeal, the Delaware Supreme Court confirmed this doctrine in Kahn v. M\&F Worldwide Corp. ${ }^{45}$

On the other side of the coin, Vice Chancellor Laster similarly endorsed the unified approach for freezeout tender offers in In re CNX Gas Corp. Shareholders Litigation. ${ }^{46}$ In In re Cox Radio, Inc. Shareholders Litigation, ${ }^{47}$ however, Vice Chancellor Parsons declined to apply the unified approach in the context of a fee determination for plaintiffs' lawyers in a freezeout tender offer.

In In re CNX Gas Corp. Shareholders Litigation, Vice Chancellor Laster granted the defendant's application to certify the question to the Delaware Supreme Court for interlocutory appeal:

The standard of review for a controller's unilateral two-step freezeout ... presents an issue of first impression for the Delaware Supreme Court. It is an issue with real-world consequences. In his study of post-Siliconix freeze-outs, Professor Guhan Subramanian found that stockholders received greater consideration in singlestep freeze-outs and negotiated two-step freeze-outs than in unilateral two-step freeze-outs. . . . Professor Subramanian noted that "[i]nterviews as well as informal conversations with New York

${ }^{41}$ In re John Q. Hammons Hotels Inc. S'holder Litig., No. 758-CC, 2009 WL 3165613 (Del. Ch. Oct. 2, 2009).

${ }^{42} I d$. at 10.

${ }^{43}$ In re MFW S'holders Litig., 67 A.3d 496 (Del. Ch. 2013).

${ }^{44} I d$. at 502 .

${ }^{45}$ See Kahn v. M\&F Worldwide Corp., 88 A.3d 635, 654 (Del. 2014).

${ }^{46}$ See In re CNX Gas Corp. S'holders Litig., 4 A.3d 397, 400 (Del. Ch. 2010). Vice Chancellor Laster added a slight adjustment to the unified standard by requiring affirmative board approval, rather than just board neutrality, in order to qualify for business judgment review. Vice Chancellor Laster analogized to the arm's-length merger process, which requires affirmative approval by the board. See id. at 420 n. 8 .

${ }^{47}$ See In re Cox Radio, Inc. S'holders Litig., No. 4461-VCP, 2010 WL 1806616, at *20 (Del. Ch. May 6, 2010). 
City and Delaware lawyers indicate that [the finding of lower returns for stockholders in Siliconix deals] is consistent with practitioner experience."

Controllers and their advisors take the governing legal regime into account when determining whether and how to proceed with a transaction. Professor Subramanian found that controllers moved decidedly towards unilateral two-step transactions after the blazing of the Siliconix-Glassman trail.

These data raise policy questions. All else equal, a legal regime that makes it easier for controllers to freeze out stockholders will increase the number of transactions but result in lower premiums. Conversely, a legal regime that imposes greater procedural requirements will enable target stockholders to receive higher premiums but reduce the overall level of transactional activity. Either approach is legitimate and defensible. Either approach could result in the greatest aggregate benefits for stockholders, depending on the typical premium and overall level of deal activity ....

Only the Supreme Court can determine definitively whether different policies, duties, and standards should govern unilateral twostep freeze-outs. Because the appropriate standard of review for unilateral two-step freeze-out presents a question of first impression for the Delaware Supreme Court and implicates fundamental issues of Delaware public policy, certification is appropriate. ${ }^{48}$

The Delaware Supreme Court nevertheless denied the appeal on the grounds that the issues raised in the case should be addressed after the entry of a final judgment. ${ }^{49}$ The next day, plaintiffs voluntarily dismissed their appeal, thereby leaving the standard of review question still unanswered. Similarly, in In re Cox Radio, Inc. Shareholders Litigation, the Delaware Supreme Court affirmed Vice Chancellor Parsons' ruling that rejected the unified approach, but because the settlement would have been approved under either entire fairness or business judgment review, the court observed that "we need not and do not express any view as to the proper standard by which the underlying transactions should be reviewed." 50

Despite the Delaware Supreme Court's endorsement of the unified approach in the specific context of merger freezeouts, there are still basic questions that remain unanswered in the aftermath of Cox, such as: (1) to what

${ }^{48}$ In re CNX Gas Corp. S'holders Litig., No. 5377-VCL, 2010 WL 2705147, at*11-13 (Del. Ch. July 5, 2010) (citations omitted). $8,2010)$

${ }^{49}$ See In re CNX Gas Corp. S'holders Litig., No. 333, 2010 WL 2690402, at *1 (Del. July 2010)

${ }^{50}$ In re Cox Radio, Inc. S'holders Litig., No. 331, 2010 WL 4721568, at*1 (Del. Nov. 22, 
extent, if at all, did the mix of freezeout tender offers and mergers change with the suggestion of a unified approach in Cox, and (2) to what extent does the difference in outcomes for the minority identified by Subramanian ${ }^{51}$ and Restrepo ${ }^{52}$ persist? This Article provides insight on the practical relevance of the unified approach to transactional outcomes and therefore, might reinforce the case for an explicit endorsement of this approach by the Delaware Supreme Court in the context of tender offer freezeouts.

\section{Methodology ${ }^{53}$}

To examine the effect of Cox, we employ a difference-in-differences approach in which the treatment group is the set of tender offer freezeouts of Delaware targets announced between June 19, 2001 (the date of the Delaware Chancery Court's opinion in Siliconix) and May 29, 2013 (the date of the Delaware Chancery Court's opinion in $M F W$ ), and the control group is the set of merger freezeouts announced in the same period. As suggested in the preceding Part, tender offers are the treatment group in this analysis because Cox proposed revising the entire fairness review exemption that Siliconix created for such transactions, and that proposed revision is expected to have produced a change in relative outcomes. ${ }^{54}$

We define the outcome of each transaction as the cumulative abnormal returns (CARs) received by target shareholders in two short-run windows ($30,+1$, and $-30,+5$ trading days relative to the announcement of the offer), and two long-run windows $(-30,+10$, and $-30,+30$ trading days relative to announcement). Abnormal returns are defined as the daily return for the target stock relative to the Center for Research in Securities Pricing (CRSP) value-weighted equities index. To calculate long-run returns for freezeouts that close before the post-deal time window has elapsed, we assume that target shareholder returns from the freezeout are re-invested into the CRSP value-weighted equities index.

The independent variables include target characteristics, controlling shareholder characteristics, and deal characteristics that may determine the magnitude of the CARs. Besides the additional controls described below,

${ }^{51}$ Subramanian, supra note 3, at 24.

${ }^{52}$ Restrepo, supra note 4, at 358 .

${ }^{53}$ In all instances, we have made methodological choices to be as consistent as possible with Subramanian's and Restrepo's papers. See Subramanian, supra note 3, at 8-10; Restrepo, supra note 4 , at $338-41$.

${ }^{54}$ We think Cox is unlikely to have affected the gains of the minority shareholders in merger freezeouts because, before and after that decision, the controller would be subject to entire fairness review if the special committee were bypassed. In addition, under the unified approach proposed in Cox, entire fairness would only be waived if an additional protection (a MOM condition) were added to the negotiation process. For these reasons, we conclude merger freezeouts can work as a control group in the analysis. We acknowledge, however, that there is still a hypothetical possibility that Cox could also have affected the gains of the minority in merger freezeouts and that, as a result, the treatment effect estimated here might not be entirely attributable to Cox's effect on tender offers. 
this analysis includes a time variable ("Post-Cox") set to one if the transaction was announced and completed after Cox and zero otherwise. It also includes a transactional form variable ("Tender offer") set to one if the freezeout was executed as a tender offer and zero if as a statutory merger. The main variable of interest is an interaction between these two variables ("Tender offer $\times$ Post-Cox"), which yields the estimator of difference-indifferences. If Cox was actually a relevant factor in closing the negative gap in outcomes between tender offers and mergers that emerged after Siliconix, this variable should be positive and, depending on the extent to which CARs have converged, it should also be significant.

In multivariate analyses, we control for the value of the transaction, the consideration offered (stock or cash), the percentage of minority shares required to approve the transaction, ${ }^{55}$ and whether the negotiation process included a special committee of independent directors. Following prior work, ${ }^{56}$ target characteristics include pre-deal efficiency and size. ${ }^{57}$ In addition, we control for acquirer characteristics such as whether the controller or its parent is a public company and whether the controller is a financial acquirer. ${ }^{58}$

As in our prior work, we begin with all transactions coded as "Acquisitions of Remaining Interest" in Thomson Financial Corporation's (TFC) Mergers \& Acquisitions database. ${ }^{59} \mathrm{We}$ identified all transactions announced between June 19, 2001 and May 29, 2013 involving Delaware corporations

55 The variable Minority Approval Required (MAR) is calculated according to the following algorithm: for a tender offer with a $90 \%$ condition, MAR $=[(90-$ controller's pre-deal stake) / $(100$ - controller's pre-deal stake $)] \times 100$. For example, a $40 \%$ controlling shareholder executing its offer through a tender offer with a $90 \%$ condition would have MAR $=[(90-40)$ / $(100-40)] \times 100=83 \%$. This is the fraction of the minority shares that the controller would need in order to satisfy the $90 \%$ condition and proceed with its back-end short-form merger. However, if the transaction is subject to a MOM condition, there is a 50\% floor on the minority required to approve the transaction. For a merger freezeout with a MOM condition, MAR $=50 \%$ (again, reflecting the fraction of minority shares required in order to proceed with the freezeout). For a tender offer freezeout without a $90 \%$ or MOM condition, or a merger freezeout without a MOM condition (where the controlling shareholder has a pre-deal stake greater than $50 \%$ of the company shares), MAR $=0$. For a merger freezeout without a MOM condition, but where the controller's pre-deal stake is less than 50\%, MAR $=[(50-$ controller's predeal stake) $/(100-$ controller's pre-deal stake $)] \times 100$. So, for example, for a controller with a $40 \%$ pre-deal stake MAR $=[(50-40) /(100-40)] \times 100=16.7 \%$, again reflecting the fraction of minority shares required in order to proceed with the transaction.

${ }^{56}$ See, e.g., Gregor Andrade, Mark Mitchell \& Erik Stafford, New Evidence and Perspectives on Mergers, 15 J. Econ. PersP. 103 (2001); Tim Loughran \& Anand M. Vijh, Do LongTerm Shareholders Benefit from Corporate Acquisitions?, 52 J. Fin. 1765 (1997).

${ }^{57}$ Ideally, the controls would be the size and pre-deal efficiency of the target relative to the size and pre-deal efficiency of the controller, respectively. Since several acquirers were not companies for which there was public information available, however, the estimations are based only on the available information for the target.

${ }^{58}$ See Leonce Bargeron, Frederik Schlingemann, René Stulz \& Chad Zutter, Why Do Private Acquirers Pay So Little Compared to Public Acquirers?, 89 J. Fin. Econ. 375 (2008) (finding public acquirers pay higher premiums on average than private acquirers); Alexander Gorbenko \& Andrey Malenko, Strategic and Financial Bidders in Takeover Auctions, $69 \mathrm{~J}$. FIN. 2513 (2014) (finding strategic and financial bidders value targets differently).

${ }^{59}$ As noted above, supra note 53, we have made methodological choices to be as consistent as possible with our prior work. Accordingly, the following description of our methodol- 
as target companies. TFC uses a 50\% cutoff to distinguish between acquisitions of remaining interests and acquisitions of a controlling interest. However, as a matter of Delaware corporate law, a shareholder with as little as a $35 \%$ holding may be considered a controlling shareholder. As such, and consistent with our previous work, we supplement TFC's remaining-interest category with transactions in which the acquirer held 35-50\% of the company at the time the freezeout was initiated. In addition, we exclude transactions where the acquirer held $90 \%$ or more of the target's voting shares (because such transactions can be executed without a shareholder vote ${ }^{60}$ ) and remaining-interest acquisitions that are the second step of a third-party tender offer (since the second step is necessarily at the same price as the first step and the first step was the result of an arm's length-negotiation ${ }^{61}$ ). Our final database includes 146 freezeouts, 80 of which were announced prior to the Delaware Chancery Court's decision in Cox and 66 afterwards.

As in our prior work, we then studied each transaction by examining the SEC filings of both the controller and the target company, news reports, and company press releases. ${ }^{62} \mathrm{We}$ collected data on the bargaining process, particularly on whether a special committee of independent directors was formed to assess the transaction, the dates and sequence of offers and counteroffers, and the terms of the final agreement (if one was reached). Stock price data are taken from the CRSP database, where available, and otherwise from DataStream.

With one exception, we classify each freezeout as either a statutory merger or a tender offer. The exception is the Lawrence Weissberg Trust's freezeout of the minority shareholders in Dover Investments, which began as a merger and was eventually executed as a tender offer. This observation was therefore excluded from the estimations. In two additional cases (the freezeout of the minority shareholders in Ticketmaster and the Roche's freezeout of the minority shareholders in Genentech), the transaction began as a tender offer but the parties ultimately entered into a merger agreement.

ogy is based in large part on the description of the methodology provided in Subramanian, supra note 3, at 8-9, and Restrepo, supra note 4, at 338-41.

${ }^{60}$ See, e.g., Del. Code AnN. tit. 8, § 253(a) (2015) (providing statutory authority of shortform mergers that do not require a shareholder vote).

${ }^{61}$ Subramanian, supra note 3, at 8-9 (citing Victor Brudney \& Marvin Chirelstein, A Restatement of Corporate Freezeouts, 87 YALE L.J. 1354, 1376 (1978) ("Two-step takeovers, being acquisitions by outsiders, are not properly to be viewed as freezeouts in the first place.")). Distinguishing an arm's-length transaction from a freezeout might not be obvious if there is a delay between the first and second steps of the transaction. See, e.g., Cede \& Co. v. Technicolor, 684 A.2d 289, 298-99 (Del. 1996). As also noted in our previous work, however, most arm's-length acquirers execute the second-step tender offer as quickly as possible in order to gain $100 \%$ of the anticipated economic benefit, avoid uncertainty in applying dissenters' appraisal rights, eliminate potential plaintiffs, delist from the stock exchange, and deregister under the Securities Exchange Act of 1934. See Subramanian, supra note 3, at 8-9. As a result, like in our previous samples, self-dealing and arm's-length transactions were clearly distinguishable, since there were not transactions in this potential gray area.

${ }^{62}$ See Subramanian, supra note 3, at 9. The SEC filings examined consisted primarily of Form 8-K, 14D-9, 13E-3, 13D, and 14A filings. 
These observations were classified according to the controller's initial expression of interest, since the execution of the merger agreement after the initiation of the tender offer was precisely the result of negotiations of the terms of the deal with the special committee of independent directors.

We classify twelve merger freezeouts that were executed as two-step tender offers as mergers because the Delaware Chancery Court has held that these transactions are subject to entire fairness review. ${ }^{63} \mathrm{We}$ also classify one freezeout that was executed as a reverse stock split (Semele Group) as a merger. Although it is a closer call, the requirement of board action that seems to distinguish mergers from tender offers is met, and the Chancery Court has subjected reverse stock splits to entire fairness review in other, non-freezeout contexts. ${ }^{64}$ The findings reported in Part III remain unchanged if we exclude this transaction from the analysis.

\section{Results}

\section{A. Descriptive Statistics}

Table 1 presents descriptive statistics. Table 1A shows that, before Cox, 24 out of 79 freezeouts (30\%) were executed as tender offers, and Table 1B shows that, after Cox, 13 out of 66 freezeouts (20\%) used this transactional form. ${ }^{65}$ Testing the difference in proportion indicates that this difference is significant (although only at 90\%), a result that generally holds in a multivariate framework (Table 10). This basic finding can be interpreted as providing some support for the intuition that Cox made the tender offer mechanism less attractive relative to the merger mechanism. However, the shift may have been muted by the fact that the unified approach was intended to level the playing field between transactional forms, rather than tilt transactional planners toward mergers and away from tender offers.

Table 1 also shows that a special committee was formed in virtually all freezeouts. The only instances in our sample (both pre- and post-Cox) in which a special committee was not formed were situations in which the target company board did not have directors who were independent of the con-

${ }^{63}$ See In re Emerging Commc'ns, Inc. S'holders Litig., No. 16415, 2004 WL 1305745, at *9 (Del. Ch. May 3, 2004) (finding freezeout merger structured as two-step tender offer subject to entire fairness review); Hartley v. Peapod, No. 19025, 2002 WL 31957458 (Del. Ch. Mar. 27, 2002).

${ }^{64}$ See Applebaum v. Avaya, 805 A.2d 209, 214 (Del. Ch. 2002).

${ }^{65}$ Examining a sample of post-Cox freezeouts announced between 2006 and 2010, Jain, Klingsberg, and Whoriskey find that 8 out of $27(30 \%)$ were executed as tender offers. Suneela Jain, Ethan Klingsberg \& Neal Whoriskey, Examining Data Points in Minority Buy-Outs: A Practitioners' Report, 36 Del. J. CoRP. L. 939, 950 (2011). The difference between our incidence finding and theirs in the post-Cox period may be due to our longer timeframe for analysis, our exclusion of non-Delaware targets, their exclusion of offers that were announced but not completed, or their exclusion of what they term "situational outliers." 
trolling shareholder (and therefore a special committee of independent directors could not be formed).

Both pre- and post-Cox, 90\% conditions in tender offer freezeouts were very common $(80+\%$ incidence). In contrast, Panel A shows that MOM conditions in merger freezeouts existed in approximately one-third of preCox transactions. As described by Subramanian, ${ }^{66}$ this relatively low frequency of MOM conditions in merger freezeouts might be the result of the little marginal benefit that this condition apparently brought about for the controller in terms of judicial intervention: Lynch provided a burden-shift on entire fairness for either special committee approval or a MOM condition, but the combination of the two (arguably) provided no incremental benefit. In fact, the puzzle with respect to pre-Cox MOM conditions may be why they were so common, given their apparently negligible value, in doctrinal terms, to the controller. Conversations with practitioners pre-Cox suggest that MOM conditions were often inserted as part of a settlement with plaintiffs, allowing the plaintiffs' attorneys to argue for a "substantial benefit" to the plaintiff class that would then justify an attorneys' fee award.

In addition, Table 1 shows that the incidence of MOM conditions in merger freezeouts increased from 33\% before Cox to 50\% after Cox. This change may reflect transactional planners' increased interest in fitting their deals into the unified approach blueprint by providing both special committee and MOM approval. However, if correct, this interpretation raises the puzzle as to why slightly more than half of mergers did not provide a MOM condition. We return to this question in Part IV below.

With respect to CARs, the univariate statistics provide some suggestive evidence that the unified approach proposed in Cox has eliminated the gap between mergers and tender offers. Before Cox, the average CARs for tender offer freezeouts in all time windows were lower than the average CARs for merger freezeouts, and this difference was significant at $95 \%$ for the $(-30$, $+1),(-30,+5)$, and $(-30,+10)$ windows. After Cox, in contrast, CARs in tender offers were actually higher, but this difference was not statistically significant at conventional levels.

Although this work focuses on CARs, increases from the first offer to the final offer (the "bump") also changed pre- and post-Cox. Before Cox, the bump in merger freezeouts $(20 \%)$ was significantly greater than the bump in tender offer freezeouts (9\%). After Cox, the bump was statistically indistinguishable between tender offers and mergers. Something similar occurred with premiums over market prices. Before Cox, premiums were higher in mergers and the difference was significant at $99 \%$ when average market prices were calculated for a period of 30 or 60 trading days prior to announcement, and at $95 \%$ when the period was ten days before announcement. In contrast, after Cox, the differences were not significant for any definition of the premium. These results are consistent with the notion that

${ }^{66}$ Subramanian, supra note 3 , at 12 . 
special committees had more leverage in tender offer freezeouts under the unified approach.

\section{B. Multivariate Analysis}

\section{Baseline Specification}

Table 2 presents the results of multivariate regressions of CARs on characteristics of the deal, the target, and the controller. In this baseline specification, we focus on transactions for which CRSP has available data (availability of CRSP data proxies for the liquidity of the target stock, which in turn permits us to focus the analysis on transactions for which CARs are most meaningful). Table 2 shows that the baseline model has reasonable fit $(\mathrm{R}-\mathrm{sq}=20+\%)$ and is generally significant. Overall, the results are consistent with the idea that Cox had at least some positive effect on CARs in tender offers. In all the specifications, the estimator of difference-in-differences ("Tender offer $\times$ Post-Cox") is positive and significant at $95 \%$ confidence, indicating that, after Cox, CARs in tender offers actually increased relative to the specific benchmark of CARs in mergers.

In terms of economic significance, the difference-in-differences coefficients indicate that, after Cox, CARs in tender offers increased relative to mergers in magnitudes of 27.04, 29.38, 28.51, and 31.85 percentage points for the $(-30,+1),(-30,+5),(-30,+10)$, and $(-30,+30)$ time windows, respectively. In other words, the post-Cox difference between the average CAR in tender offers and the average CAR in mergers, after subtracting the pre-Cox difference between both transactional forms, is approximately equivalent to these magnitudes for each time window.

The regressions also show that the coefficient of the post-Cox variable is negative and significant at $90 \%$, reflecting a decline in the average CARs of mergers. On the other hand, the tender offer variable, which measures the pre-Cox difference in CARs between tender offers and mergers, is negative in all the specifications and significant at $95 \%$. This is consistent with the results in Table 1, which also shows that CARs in tender offers were lower than CARs in mergers before Cox.

\section{Alternative Specifications}

Because the foregoing analysis indicates that Cox appears to have had a positive and statistically significant effect on relative CARs in tender offer freezeouts, this section tests the stability of the results across seven alternative specifications: (1) weighting observations by the market capitalization of the target; (2) weighting observations by the difference between the incidence of each transactional form before and after Cox; (3) using the full sample, including relatively illiquid targets; (4) using a subsample that in- 
cludes only pre- $C N X$ transactions; (5) using standard errors that correct potential serial autocorrelation (Newey-West adjusted errors); (6) using standard errors that correct potential cross-sectional dependence (DiscrollKraay regressions); and (7) using a Huber-White specification that controls for the effect of outliers or highly influential observations.

Table 3 shows the results of the regressions weighted by the market capitalization of the target. With this adjustment, the difference-in-differences estimator remains positive and significant at $95 \%$. In unreported regressions, we also weight the observations by the logarithm of assets of the target and by the logarithm of deal value. In both instances, the sign and significance of the difference-in-differences estimator were similar to the results reported in Table 3.

Because the sample is not balanced (in the sense that the proportion of tender offers and mergers is not the same before and after Cox), the regressions were also run as weighted specifications in which the weight assigned to each observation was the incidence difference between the two transactional forms in the two periods examined here. The results are reported in Table 4, which shows that the estimations are similar to the baseline specification. Moreover, as an alternative to this weight, the regressions were also weighted by the logarithm of the incidence ratio and the logarithm of the odds ratio of each transactional form before and after Cox. With these specifications, the difference-in-differences estimator was again positive and significant at least at $95 \%$.

Table 5 shows the results of regressions that are similar to the baseline specifications, except for the fact that illiquid companies (that is, companies with no CRSP data available) are also included in the database. The table shows that the sign of the difference-in-differences estimator remains positive, although significant only at $90 \%$ confidence interval (except in one specification, in which it was not significant).

It might be argued that part of the increase in relative prices in tender offers after Cox was driven by CNX Gas because that decision explicitly endorsed, with respect to tender offers, the unified standard of review proposed in Cox (even though the Chancery Court ultimately deferred this question to the Delaware Supreme Court). As a consequence, the positive sign of the difference-in-differences estimator might be capturing the effect of these two decisions. Although most of the sample of this work is actually composed of transactions between Siliconix and $C N X$, the analysis was repeated only with pre- $C N X$ transactions. As Table 6 shows, the results were generally similar to the baseline estimations except in one specification, in which the $p$-value of the difference-in-differences estimator was 0.051 (and, therefore, the variable is reported as significant at $90 \%$ ).

We also ran the model with Newey-West adjustments to the standard errors, which are robust to both serial autocorrelation and heteroskedasticity. As Table 7 shows, after the adjustment, the estimator of difference-in-differences keeps positive and significant at $95 \%$ in all the specifications. As an 
alternative to this adjustment, the baseline regressions were also run with lags of the dependent variable. This also produced results that were similar to the baseline estimations and statistically insignificant lags. This exercise was repeated, with similar results, using first- to fourth-order lags, which were introduced sequentially into the regressions.

To control for cross-sectional dependence, the regressions were also run using Driscoll-Kraay standard errors. More specifically, this form of the standard errors was employed to test whether the results hold when it is assumed that the residuals of the model might be correlated not only within, but also between different groups (in this case, particularly between groups of industries). The results are presented in Table 8, which shows that, with this adjustment, the sign and significance of the difference-in-differences estimator is similar to the baseline regressions.

As an alternative to the Discroll-Kraay errors, the regressions were also run in unreported regressions using industry-fixed effects. To this end, each target was classified into an economic sector based on its Thomson Financial macro-level industry classification, which, in turn, is based on the Standard Industry Classification (SIC) and North American Industry Classification (NAIC) codes of the company. In this case again, the estimator of difference-in-differences was positive and significant at $95 \%$ in all the specifications.

Finally, to control for the effect of outliers or highly influential observations, the regressions were run again as Huber-White specifications, which weight all the observations in function of their residual: the larger the residual, the lower the weight assigned to that observation. With this specification, the regressions again produce a positive and statistically significant difference-of-differences estimator (Table 9).

Besides the concerns that the alternative specifications discussed above seek to address, one additional concern is potential selection bias. Controlling shareholders can decide what transactional form to use in a freezeout, which implies that there might be changes in the characteristics of the treatment group, the control group, or both as a result of Cox. This can ultimately have an effect on CARs. The analysis presented in Part III.A, however, does not reveal changes in the composition of the treatment and the control group that would clearly favor the hypothesis of a positive effect of Cox. In addition, there is no clear unobservable characteristic that should be expected to have changed as a result of Cox in a way that would increase CARs in tender offers relative to CARs in mergers. Furthermore, the mechanisms that could be used to correct for selection bias are limited here. In particular, there is no clear group of transactions that has a stable composition over time, that produces similar economic outcomes, and that, therefore, could work as an alternative control group ${ }^{67}$ In addition, there is no clear variable that could be

${ }^{67}$ One possible solution, in particular, could be to use freezeouts of non-Delaware targets as a control group. This is not, however, a stable benchmark, since the composition of states in 
used as an instrument in a two-stage regression or as a mechanism to address the endogeneity of the treatment choice via Heckman regressions. Further, matching on observables is problematic due to the size of the sample. In light of these considerations, merger freezeouts seem to provide the best control group available to estimate the treatment effect of Cox, even though the risk of self-selection cannot be conclusively ruled out here.

\section{Deal Incidence Analysis}

To examine whether the relative incidence of tender offers decreased after Cox (especially because controllers might have seen that decision as a threat to the potential benefits associated with the exemption from entire fairness created by Siliconix), we tested the difference in proportion for the pre-Cox and post-Cox tranches of the database. As mentioned in Part III.A, the test indicates that the relative incidence of tender offers is lower after Cox, although the difference is only significant at $90 \%$. In addition, to control for characteristics of the target, the controller and the deal that might affect the choice of the transactional form, we ran a logit specification in which the dependent variable was the transactional form variable and the independent variable of interest was the post-Cox dummy. As shown in Table 10, the post-Cox variable was always negative and generally significant at $90 \%$. This confirms that Cox, in fact, seems to have played at least some role in decreasing the number of tender offers after $2005 .{ }^{68}$

\section{Discussion}

Taken as a whole, the results have several implications. First, for transactional practice, the results confirmed practitioner intuitions that Cox reduced the benefits of the Siliconix and Glassman "get out of jail free card." Post-Cox, practitioners used the tender offer freezeout mechanism less often, and, when it was used, minority shareholders received higher relative CARs

which freezeouts took place during the sample period is not the same before and after Cox. Moreover, since other states usually follow Delaware in corporate law, it is possible that Cox influenced the behavior of controlling shareholders (and, therefore, the gains of the minority shareholders) outside Delaware, which would accentuate the problem of potential bias if this alternative control group were used.

${ }^{68}$ The first model in Table 10 does not include the size of the deal because that factor might be endogenous to the choice of the transactional form, but specifications 2 and 4 present the results of regressions with that variable. On the other hand, although the required minority vote might be a factor that determines the choice of the transactional form, that aspect also can be endogenous to the structure of the deal. The required minority approval, in fact, is affected by the presence of a MOM condition, which in turn can be determined by the negotiation of the terms of the deal with the target (and, therefore, by the choice of the transactional structure). In light of this, the first two specifications in Table 10 present the results of regressions with the proportion of shares sought in the deal, but specifications 3 and 4 also present the results of regressions with the actual minority vote required. These two specifications thus assume that the decision to include a MOM provision in the terms of the deal precedes the choice of the deal structure. 
compared to the pre-Cox period. Of course, this result must be interpreted with some caution, given the sample size. However, we take some comfort from the fact that our analysis included all freezeouts of Delaware targets between Siliconix and $M F W$. In addition, we tried to mitigate small-sample concerns by running various robustness tests on our sample, including weighting our dataset by deal size, target size, and differences in incidence proportions before and after Cox.

In general, the results provided a case study on the responsiveness of transactional practice to changes in doctrine. When Siliconix and Glassman opened up a window, practitioners made use of it to benefit their controlling shareholder clients. When Cox suggested that the window might be closing, practitioners backed away. An unpublished version of Subramanian's paper ${ }^{69}$ reported that more experienced law firms (based on prior M\&A experience) were more likely to recommend the tender offer mechanism after Siliconix and Glassman, relative to less experienced firms. In this Article, we have not collected data on law firms advising controlling shareholders because our non-finding on post-Cox differences in deal outcomes makes the choice of transactional form less important, and therefore less interesting to examine. Nevertheless, the overall picture illustrates how sophisticated transactional planners can and do respond to even dicta pronouncements in Delaware corporate law.

In terms of policy, our findings have mixed implications. In response to Pritchard ${ }^{70}$ and others ${ }^{71}$ who argued that the Siliconix and Glassman contour merely created a one-time wealth transfer from minority shareholders to controlling shareholders, Subramanian ${ }^{72}$ described how the difference in judicial standards of review could create a social welfare loss by permitting opportunistic tender offer freezeouts at below the intrinsic value of minority shares and preventing merger freezeouts even if above intrinsic value. In this Article we do not present direct evidence on whether some value-creating merger freezeouts were deterred, simply because deal deterrence is inherently non-observable. However, on the tender offer side, our results suggest that the unified approach has reduced the opportunity for (and possibility of) freezeouts below intrinsic value. Put simply, by closing the gap (even in the form of dicta) between judicial review of tender offer freezeouts and merger freezeouts, the unified approach proposed in Cox has reduced and perhaps eliminated the social welfare loss identified by Subramanian. ${ }^{73}$

On the merger side, the incidence of MOM conditions has increased since Cox, from $33 \%$ to $50 \%$, but this still leaves approximately half of all merger freezeouts without a meaningful shareholder approval requirement.

${ }^{69}$ Subramanian, supra note 3, at 20 n. 12 .

${ }^{70}$ Adam Pritchard, Tender Offers by Controlling Shareholders: The Specter of Coercion and Fair Price, 1 Berkeley Bus. L.J. 83, 103 (2004).

${ }^{71}$ See Robert C. Clark, Corporate Law 506 (1986).

${ }^{72}$ Subramanian, supra note 5, at 31-48.

${ }^{73} \mathrm{Id}$. 
One interpretation of this finding is that the benefit of providing a MOM condition, conditional on special committee approval, was unclear at best. As Chancellor Strine colorfully analogized in $M F W$, "Assume you have a teenager with math and English assignments due Monday morning. If you tell the teenager that she can go to the movies on Saturday night if she completes her math or English homework Saturday morning, she is unlikely to do both assignments Saturday morning." ${ }^{4}$ To translate to the freezeout context, Kahn v. Lynch offered a burden shift for either special committee or MOM approval, but it was not clear that there would be a further benefit for the inclusion of both procedural protections. ${ }^{75}$ Only with the $M F W$ case did the Delaware courts provide a clear incentive_-business judgment reviewfor including both.

Defenders of the status quo might argue that the special committee approval process (which continues to be very common in post-Cox freezeouts) provides sufficient protection for minority shareholders, but Subramanian ${ }^{76}$ explains how special committee approval and a MOM condition serve substantially different purposes: the former is a back-and-forth and typically hard-fought negotiation between the controller and representatives of the minority, while the latter provides a binary check against a captured special committee. ${ }^{77}$ For this reason, it is our view that the Delaware Supreme Court adopted the correct policy by endorsing the unified approach for merger freezeouts in Kahn v. M\&F Worldwide Corp., and that, moreover, the court should also explicitly endorse this approach in the context of tender offer freezeouts when presented with such facts.

\section{Conclusion}

All good things must come to an end. The results presented by Subramanian, ${ }^{78}$ Restrepo ${ }^{79}$ and this Article provide an illustration of this fact. In 2001, the combination of Siliconix and Glassman opened up a window for

${ }^{74}$ In re MFW S'holders Litig., 67 A.3d 496, 500-01 (Del. Ch. 2013).

${ }^{75}$ Even after 2005, this was still true possibly because, in the specific context of merger freezeouts, some transactional planners considered that Cox could not introduce an exemption from entire fairness review. This is because (1) as mentioned, Lynch did not explicitly permit any safe harbor for this transactional form, and (2) Lynch was a Delaware Supreme Court decision, which could not be modified by a Chancery Court opinion.

${ }^{76}$ Subramanian, supra note 5, at 53-54.

${ }^{77}$ See also In re MFW S'holders Litig., 67 A.3d at 503 ("A transactional structure with both these protections [special committee approval and MOM condition] is fundamentally different from one with only one protection. A special committee alone ensures only that there is a bargaining agent who can negotiate price and address the collective action problem facing stockholders, but it does not provide stockholders any chance to protect themselves. A majority-of-the-minority vote provides stockholders a chance to vote on a merger proposed by a controller-dominated board, but with no chance to have an independent bargaining agent work on their behalf to negotiate the merger price .... These protections are therefore incomplete and not substitutes, but are complementary and effective in tandem.").

${ }_{79}^{78}$ Subramanian, supra note 3.

${ }^{79}$ Restrepo, supra note 4. 
practitioners to execute a freezeout of minority shareholders without significant judicial scrutiny. Our evidence indicates that practitioners took advantage of this doctrinal contour by increasing the use of the tender offer mechanism and paying lower prices to minority shareholders when they did so. Cox subsequently proposed a unified approach to close the window and transactional planners responded by reducing the use of tender offers and, when they were used, by increasing the deal price.

The evidence, then, provides a case study on how practitioners respond to even dicta pronouncements in Delaware case law. In addition, the evidence indicates that Cox seems to have eliminated the efficiency loss identified by Subramanian. ${ }^{80}$ This in turn suggests that the Delaware Supreme Court probably implemented the correct policy by endorsing the unified approach in the context of merger freezeouts, and that, consequently, the court should also explicitly endorse that approach for tender offers if a case of this kind were presented to the court.

${ }^{80}$ Subramanian, supra note 5. 


\section{TABLE 1 \\ Summary Statistics: Pre and Post Cox Freezeouts}

Panels A and B of Table 1 report summary statistics for tender offer and merger freezeouts before and after Cox. The pre-Cox tranche of the sample is the period from June 19, 2001 through June 6, 2005. The post-Cox tranche is the period from June 6, 2001 through December 2012. Standard deviations are presented in parentheses. Dover Investments is not included in the summary statistics because it was not classified as a tender offer or as a merger. The measure for the pre-deal efficiency of the target is the company's ROA in the twelve months immediately preceding the announcement of the transaction and the measure of the size is the target's assets at the same point in time. CARs are winsorized at $5 \%$. $*$ significant at $10 \%, * *$ significant at $5 \%, * * *$ significant at $1 \%$.

Panel A. Pre-Cox Freezeouts by Transactional Form

\begin{tabular}{|c|c|c|c|}
\hline Variable & $\begin{array}{c}\text { Tender } \\
\text { offers }\end{array}$ & Mergers & All \\
\hline \multicolumn{4}{|l|}{ Transaction characteristics } \\
\hline Transaction value & $\begin{array}{c}592.88 \\
(1434.00)\end{array}$ & $\begin{array}{c}298.59 \\
(1239.06)\end{array}$ & $\begin{array}{c}384.48 \\
(1292.18)\end{array}$ \\
\hline Percentage of shares sought in transaction (\%) & $\begin{array}{c}29.98 \\
(11.83)\end{array}$ & $\begin{array}{c}38.33 \\
(12.82)\end{array}$ & $\begin{array}{l}35.98 \\
(13.07)\end{array}$ \\
\hline Stock consideration (\%) & 37.5 & 20 & 25 \\
\hline Special committee formation $(\%)$ & 91.67 & 94.54 & 93.75 \\
\hline $\begin{array}{l}\text { Non-waivable majority-of-the-minority or } 90 \% \text { tender } \\
\text { condition }(\%)\end{array}$ & 83.33 & 32.69 & 48.68 \\
\hline Special committee and MOM or $90 \%$ condition & 79.17 & 32.69 & 47.36842 \\
\hline \multicolumn{4}{|l|}{ Transaction outcomes } \\
\hline $\begin{array}{l}\text { CARs }[-30,+1] \\
\text { CARs }[-30,+5] \\
\text { CARs }[-30,+10] \\
\text { CARs }[-30,+30] \\
\text { Premiums over market prices }\end{array}$ & $\begin{array}{l}18.29^{* *} \\
17.35^{* *} \\
17.16^{* *} \\
17.62^{*}\end{array}$ & $\begin{array}{l}41.38 * * \\
40.39 * * \\
39.57 * * \\
39.79 *\end{array}$ & $\begin{array}{l}32.72 \\
31.75 \\
31.17 \\
31.48\end{array}$ \\
\hline $\begin{array}{l}1 \text { day prior to announcement } \\
10 \text { day prior to announcement } \\
30 \text { days prior to announcement } \\
60 \text { days prior to announcement }\end{array}$ & $\begin{array}{c}30.06 \\
25.26^{* *} \\
19.18^{* * *} \\
13.10^{* * *}\end{array}$ & $\begin{array}{c}36.02 \\
44.01 * * \\
46.13 * * * \\
43.68 * * *\end{array}$ & $\begin{array}{l}33.75 \\
36.85 \\
35.84 \\
32.01\end{array}$ \\
\hline Increase over first offer & $9.30 * *$ & $20.49 * *$ & 15.92 \\
\hline Deal completion rate $(\%)$ & 87.5 & 72.72 & 78.48 \\
\hline \multicolumn{4}{|l|}{ Target characteristics } \\
\hline $\begin{array}{l}\text { Size of the target (million dollars) } \\
\text { Pre-deal efficiency }\end{array}$ & $\begin{array}{c}2953.31 \\
-11.48\end{array}$ & $\begin{array}{l}844.87 \\
-31.63\end{array}$ & $\begin{array}{c}1467.56 \\
-25.13\end{array}$ \\
\hline \multicolumn{4}{|l|}{ Controller characteristics } \\
\hline $\begin{array}{l}\text { Public status }(\%) \\
\text { Financial acquirer }(\%) \\
\text { Percentage of shares held prior to the transaction (\%) }\end{array}$ & $\begin{array}{c}75 \\
8.33 \\
69.76 \\
(12.41)\end{array}$ & $\begin{array}{c}41.82 \\
10.91 \\
61.64 \\
(12.84)\end{array}$ & $\begin{array}{c}51.25 \\
10 \\
63.92 \\
(13.20)\end{array}$ \\
\hline Number of observations & 24 & 55 & 79 \\
\hline
\end{tabular}


Panel B. Post-Cox Freezeouts by Transactional Form

\begin{tabular}{|c|c|c|c|}
\hline Variable & $\begin{array}{l}\text { Tender } \\
\text { offers }\end{array}$ & Mergers & All \\
\hline \multicolumn{4}{|l|}{ Transaction characteristics } \\
\hline Transaction value & $\begin{array}{c}3872.44 \\
(12871.19)\end{array}$ & $\begin{array}{c}644.26 \\
(1367.32)\end{array}$ & $\begin{array}{c}1299.98 \\
(5895.18)\end{array}$ \\
\hline Percentage of shares sought in transaction (\%) & $\begin{array}{c}35.47 \\
(14.17)\end{array}$ & $\begin{array}{c}42.26 \\
(14.30)\end{array}$ & $\begin{array}{c}40.92 \\
(14.42)\end{array}$ \\
\hline Stock consideration $(\%)$ & 23.08 & 20.75 & 21.21 \\
\hline Special committee formation (\%) & 92.308 & 98.11 & 96.97 \\
\hline $\begin{array}{l}\text { Non-waivable majority-of-the-minority or } 90 \% \text { tender } \\
\text { condition }(\%) \\
\text { Special committee and MOM or } 90 \% \text { condition }\end{array}$ & $\begin{array}{l}84.61 \\
84.61\end{array}$ & $\begin{array}{l}50 \\
50\end{array}$ & $\begin{array}{l}57.38 \\
57.38\end{array}$ \\
\hline \multicolumn{4}{|l|}{ Transaction outcomes } \\
\hline $\begin{array}{l}\text { CARs }[-30,+1] \\
\text { CARs }[-30,+5] \\
\text { CARs }[-30,+10] \\
\text { CARs }[-30,+30] \\
\text { Premiums over market prices }\end{array}$ & $\begin{array}{l}21.74 \\
23.33 \\
22.03 \\
24.59\end{array}$ & $\begin{array}{l}19.87 \\
19.89 \\
19.25 \\
19.01\end{array}$ & $\begin{array}{l}20.31 \\
20.70 \\
19.90 \\
20.32\end{array}$ \\
\hline $\begin{array}{l}1 \text { day prior to announcement } \\
10 \text { days prior to announcement } \\
30 \text { days prior to announcement } \\
60 \text { days prior to announcement }\end{array}$ & $\begin{array}{l}55.05 \\
58.34 \\
47.09 \\
33.06\end{array}$ & $\begin{array}{l}38.43 \\
38.50 \\
37.32 \\
37.42\end{array}$ & $\begin{array}{l}42.37 \\
43.20 \\
39.64 \\
36.39\end{array}$ \\
\hline Increase over first offer $(\%)$ & 21.96 & 16.27 & 17.73 \\
\hline Deal completion rate $(\%)$ & 76.92 & 69.81 & 71.21 \\
\hline \multicolumn{4}{|l|}{ Target characteristics } \\
\hline Size of the target (million dollars) & $\begin{array}{c}2899.94 \\
(5791.04)\end{array}$ & $\begin{array}{c}5556.31 \\
(18115.51)\end{array}$ & $\begin{array}{c}5016.74 \\
(16370.76)\end{array}$ \\
\hline Pre-deal efficiency & $\begin{array}{c}-7.73 \\
(23.15)\end{array}$ & $\begin{array}{c}-8.43 \\
(34.88)\end{array}$ & $\begin{array}{c}-8.30 \\
(32.75)\end{array}$ \\
\hline \multicolumn{4}{|l|}{ Controller characteristics } \\
\hline $\begin{array}{l}\text { Public status }(\%) \\
\text { Financial acquirer }(\%) \\
\text { Percentage of shares held prior to the transaction }(\%)\end{array}$ & $\begin{array}{c}46.15 \\
7.69 \\
64.53 \\
(14.17) \\
13\end{array}$ & $\begin{array}{c}49.05 \\
13.21 \\
57.64 \\
(14.05) \\
53\end{array}$ & $\begin{array}{c}48.48 \\
12.12 \\
59.00 \\
(14.23) \\
66\end{array}$ \\
\hline
\end{tabular}




\section{TABLE 2 \\ Multivariate Analysis}

Table 2 reports regressions estimates on the association between freezeout CARs and the characteristics of the transaction, the target and the controller. The dependent variables are the target's CARs over the time windows -30 to $+1,-30$ to $+5,-30$ to +10 , and -30 to +30 trading days relative to the announcement of the transaction. All models are run as ordinary least squares (OLS) with intercept (not reported here) and with heteroskedasticity-consistent standard errors (in parentheses). * significant at $90 \%$ confidence; $* *$ significant at $95 \%$ confidence; $* * *$ significant at $99 \%$ confidence.

\begin{tabular}{lcccc}
\hline \multicolumn{1}{c}{ Variable } & CARs & CARs & CARs & CARs \\
& {$[-30,+1]$} & {$[-30,+5]$} & {$[-30,+10]$} & {$[-30,+30]$} \\
\hline Tender offer $\times$ Post-Cox & $27.04^{* *}$ & $29.38^{* *}$ & $28.51^{* *}$ & $31.85^{* *}$ \\
& $(11.40)$ & $(11.47)$ & $(12.15)$ & $(13.72)$ \\
Tender offer & $-20.30^{* *}$ & $-21.65^{* * *}$ & $-21.94^{* *}$ & $-23.00^{* *}$ \\
& $(7.85)$ & $(8.25)$ & $(8.90)$ & $(10.80)$ \\
Post-Cox & $-18.83^{* *}$ & $-18.93^{* *}$ & $-18.99^{* *}$ & $-21.36^{* *}$ \\
& $(8.20)$ & $(8.16)$ & $(8.34)$ & $(9.72)$ \\
Transaction value (logarithm of the value & & & & \\
in millions) & $-7.64^{* *}$ & $-7.63^{* *}$ & $-7.71^{* *}$ & $-8.35^{* *}$ \\
& $(3.46)$ & $(3.50)$ & $(3.53)$ & $(3.91)$ \\
Stock consideration & $-18.92^{* *}$ & $-18.87^{* *}$ & $-20.92^{* * *}$ & $-25.29^{* * *}$ \\
& $(7.34)$ & $(7.38)$ & $(7.62)$ & $(9.53)$ \\
Minority approval required $(\%)$ & -0.06 & -0.04 & -0.02 & 0.02 \\
& $(0.14)$ & $(0.14)$ & $(0.15)$ & $(0.18)$ \\
Special committee formation & $20.66^{* *}$ & $20.45^{* *}$ & $23.05^{* *}$ & $45.62^{* *}$ \\
& $(10.26)$ & $(10.26)$ & $(11.23)$ & $(17.53)$ \\
Size of the target (logarithm total assets) & 4.67 & 4.95 & 4.43 & 4.27 \\
& $(3.13)$ & $(3.24)$ & $(3.23)$ & $(3.54)$ \\
Pre-deal efficiency (ROA) & 0.00 & 0.03 & 0.07 & 0.17 \\
& $(0.10)$ & $(0.11)$ & $(0.11)$ & $(0.16)$ \\
Public status of controller or parent of & & & & \\
controller & $15.45^{*}$ & $15.25^{*}$ & $17.24 *$ & $19.99^{*}$ \\
& $(8.99)$ & $(8.99)$ & $(9.42)$ & $(10.92)$ \\
Financial acquirer & 1.26 & 0.35 & -0.89 & 3.44 \\
& $(9.40)$ & $(8.77)$ & $(9.49)$ & $(11.05)$ \\
R-squared & 0.2071 & 0.2037 & 0.2023 & 0.201 \\
$F$-statistic & 2.16 & 1.97 & 1.8 & 2.12 \\
$P$-value (Prob $>$ F) & 0.0238 & 0.041 & 0.0661 & 0.0267 \\
Number of observations & 100 & 100 & 100 & 100 \\
\hline
\end{tabular}




\section{TABLE 3 \\ Sensitivity AnAlysis}

Regressions Weighted by Market Capitalization of the Target

Table 3 presents regression estimates after weighting each observation by the market capitalization of the target. The dependent variables are the target's CARs over the time windows -30 to $+1,-30$ to $+5,-30$ to +10 , and -30 to +30 trading days relative to the announcement of the transaction. All models are run as OLS with intercept (not reported here) and heteroskedasticity-consistent standard errors. $*$ significant at $90 \%$ confidence; $* *$ significant at $95 \%$ confidence; $* * *$ significant at $99 \%$ confidence.

\begin{tabular}{lcccc}
\hline \multicolumn{1}{c}{ Variable } & CARs & CARs & CARs & CARs \\
& {$[-30,+1]$} & {$[-30,+5]$} & {$[-30,+10]$} & {$[-30,+30]$} \\
\hline Tender offer $\times$ Post-Cox & $25.84^{* *}$ & $28.51^{* * *}$ & $27.50^{* *}$ & $28.76^{* *}$ \\
& $(10.23)$ & $(10.55)$ & $(11.15)$ & $(12.11)$ \\
Tender offer & $-20.42^{* *}$ & $-21.35^{* *}$ & $-21.33^{* *}$ & $-22.15^{* *}$ \\
& $(7.97)$ & $(8.44)$ & $(8.97)$ & $(10.42)$ \\
Post-Cox & $-18.04^{* *}$ & $-18.23^{* *}$ & $-18.79^{* *}$ & $-20.07^{* *}$ \\
& $(7.55)$ & $(7.64)$ & $(7.76)$ & $(8.91)$ \\
Transaction value (logarithm of the value & $-5.84^{*}$ & $-5.96^{*}$ & $-6.06^{*}$ & $-6.55^{*}$ \\
in millions) & $(3.27)$ & $(3.40)$ & $(3.37)$ & $(3.59)$ \\
Stock consideration & $-17.30^{* *}$ & $-17.67^{* *}$ & $-19.60^{* * *}$ & $-21.79^{* *}$ \\
& $(7.25)$ & $(7.36)$ & $(7.25)$ & $(8.72)$ \\
Minority approval required $(\%)$ & -0.05 & -0.05 & -0.03 & 0.02 \\
& $(0.12)$ & $(0.12)$ & $(0.13)$ & $(0.15)$ \\
Special committee formation & $19.34^{*}$ & $20.00^{*}$ & $24.09^{* *}$ & $49.18^{* * *}$ \\
& $(10.63)$ & $(10.43)$ & $(10.80)$ & $(14.94)$ \\
Size of the target (logarithm total assets) & 3.67 & 4.17 & 3.80 & 3.71 \\
& $(3.18)$ & $(3.35)$ & $(3.31)$ & $(3.55)$ \\
Pre-deal efficiency (ROA) & 0.00 & 0.03 & 0.07 & 0.17 \\
& $(0.10)$ & $(0.11)$ & $(0.12)$ & $(0.17)$ \\
Public status of controller or parent & $14.95^{*}$ & $14.93^{*}$ & $16.76^{* *}$ & $18.34^{*}$ \\
of controller & $(8.06)$ & $(8.25)$ & $(8.38)$ & $(9.60)$ \\
Financial acquirer & 5.46 & 4.29 & 3.60 & 7.27 \\
& $(7.36)$ & $(7.36)$ & $(8.05)$ & $(9.43)$ \\
R-squared & 0.205 & 0.1988 & 0.2008 & 0.1989 \\
$F$-statistic & 2.23 & 1.99 & 1.89 & 2.64 \\
$P$-value (Prob $>$ F) & 0.0194 & 0.0389 & 0.0519 & 0.0058 \\
Number of observations & 99 & 99 & 99 & 99 \\
\hline
\end{tabular}




\section{TABLE 4 \\ SENSITIVITy ANALYSis \\ Regressions Weighted by Difference in Transactional Form INCIDENCE}

Table 4 reports the results of weighted regressions in which the weight is the difference in deal incidence between tender offers and mergers before and after Cox. The dependent variables are the target's CARs over the time windows -30 to $+1,-30$ to $+5,-30$ to +10 , and -30 to +30 trading days relative to the announcement of the transaction. All models are run as ordinary least squares (OLS) with intercept (not reported here) and heteroskedasticity-consistent standard errors (in parentheses). ${ }^{*}$ significant at $90 \%$ confidence; $* *$ significant at $95 \%$ confidence; $* * *$ significant at $99 \%$ confidence.

\begin{tabular}{lcccc}
\hline \multicolumn{1}{c}{ Variable } & CARs & CARs & CARs & CARs \\
& {$[-30,+1]$} & {$[-30,+5]$} & {$[-30,+10]$} & {$[-30,+30]$} \\
\hline Tender offer $\times$ Post-Cox & $26.15^{* *}$ & $28.64^{* *}$ & $27.61^{* *}$ & $31.18^{* * *}$ \\
& $(11.61)$ & $(11.65)$ & $(12.27)$ & $(13.78)$ \\
Tender offer & $-21.19^{* *}$ & $-22.58^{* * *}$ & $-22.42^{* *}$ & $-23.92^{* *}$ \\
& $(8.23)$ & $(8.55)$ & $(9.05)$ & $(10.78)$ \\
Post-Cox & $-19.34^{* *}$ & $-19.48^{* *}$ & $-19.39^{* *}$ & $-22.09^{* *}$ \\
& $(8.66)$ & $(8.55)$ & $(8.75)$ & $(10.20)$ \\
Transaction value (logarithm of the value & $-5.70^{*}$ & $-5.82^{*}$ & $-5.82^{*}$ & $-6.35^{*}$ \\
in millions) & $(3.26)$ & $(3.29)$ & $(3.32)$ & $(3.66)$ \\
Stock consideration & $-18.67^{* *}$ & $-18.44^{* *}$ & $-20.60^{* * *}$ & $-24.80^{* * *}$ \\
& $(7.32)$ & $(7.34)$ & $(7.46)$ & $(9.39)$ \\
Minority approval required $(\%)$ & -0.03 & -0.02 & 0.00 & 0.04 \\
& $(0.13)$ & $(0.13)$ & $(0.13)$ & $(0.16)$ \\
Special committee formation & $17.64^{*}$ & $17.77^{*}$ & $20.18^{*}$ & $42.59^{* *}$ \\
& $(10.63)$ & $(10.40)$ & $(11.29)$ & $(17.40)$ \\
Size of the target (logarithm total assets) & 3.39 & 3.80 & 3.19 & 3.16 \\
& $(3.05)$ & $(3.16)$ & $(3.16)$ & $(3.46)$ \\
Pre-deal efficiency (ROA) & -0.02 & 0.01 & 0.05 & 0.14 \\
& $(0.10)$ & $(0.10)$ & $(0.11)$ & $(0.16)$ \\
Public status of controller or parent & $13.91^{*}$ & $13.82^{*}$ & $15.68^{*}$ & $18.31^{*}$ \\
of controller & $(8.57)$ & $(8.60)$ & $(8.88)$ & $(10.29)$ \\
Financial acquirer & 1.04 & 0.44 & -1.40 & 2.17 \\
& $(8.96)$ & $(8.20)$ & $(8.76)$ & $(9.90)$ \\
R-squared & 0.1863 & 0.1809 & 0.1817 & 0.1809 \\
$F$-statistic & 2.04 & 1.9 & 1.74 & 2.05 \\
$P$-value (Prob >F) & 0.0335 & 0.0506 & 0.0772 & 0.0331 \\
Number of observations & 100 & 100 & 100 & 100 \\
\hline
\end{tabular}




\section{TABLE 5 \\ SENSITIVITy ANALysis \\ Liquid and Relatively Illiquid Companies}

Table 5 presents the results of running again the baseline regressions with liquid and relatively illiquid companies. Liquid companies are defined as companies for which there was CRSP information available and illiquid companies are targets for which this was not the case. The dependent variables are the target's CARs over the time windows -30 to +1 , -30 to $+5,-30$ to +10 , and -30 to +30 trading days relative to the announcement of the transaction. In all the models, CARs are winsorized at 5\%. All models are run as ordinary least squares (OLS) with intercept (not reported here) and with heteroskedasticity-consistent standard errors (in parentheses). $*$ significant at $90 \%$ confidence; $* *$ significant at $95 \%$ confidence; $* * *$ significant at $99 \%$ confidence.

\begin{tabular}{lcccc}
\hline \multicolumn{1}{c}{ Variable } & CARs & CARs & CARs & CARs \\
& {$[-30,+1]$} & {$[-30,+5]$} & {$[-30,+10]$} & {$[-30,+30]$} \\
\hline Tender offer $\times$ Post-Cox & $16.90^{*}$ & $18.24^{*}$ & $17.81^{*}$ & 17.04 \\
& $(9.58)$ & $(9.83)$ & $(10.14)$ & $(11.12)$ \\
Tender offer & $-14.31^{*}$ & $-14.98^{*}$ & $-15.37 *$ & -13.55 \\
& $(7.49)$ & $(7.74)$ & $(8.07)$ & $(9.13)$ \\
Post-Cox & -7.45 & -7.41 & -7.50 & -6.62 \\
& $(6.33)$ & $(6.39)$ & $(6.37)$ & $(7.20)$ \\
Transaction value (logarithm of the value & $-5.16^{* *}$ & $-4.54^{*}$ & $-4.15^{*}$ & -3.79 \\
in millions) & $(2.31)$ & $(2.30)$ & $(2.33)$ & $(2.78)$ \\
Stock consideration & $-18.12^{* * *}$ & $-19.41^{* * *}$ & $-20.01 * * *$ & $-21.41^{* * *}$ \\
& $(6.20)$ & $(6.39)$ & $(6.45)$ & $(7.37)$ \\
Minority approval required (\%) & 0.03 & 0.03 & 0.05 & 0.09 \\
& $(0.11)$ & $(0.11)$ & $(0.11)$ & $(0.13)$ \\
Special committee formation & 4.82 & 2.83 & 3.96 & 12.49 \\
& $(13.09)$ & $(13.07)$ & $(13.12)$ & $(15.62)$ \\
Size of the target (logarithm total assets) & 2.09 & 1.73 & 1.15 & 0.46 \\
& $(2.31)$ & $(2.36)$ & $(2.37)$ & $(2.79)$ \\
Pre-deal efficiency (ROA) & 0.01 & 0.01 & 0.02 & \\
& $(0.03)$ & $(0.03)$ & $(0.04)$ & $(0.04)$ \\
Public status of controller or parent & $14.22^{* *}$ & $13.62^{* *}$ & $14.33^{* *}$ & $13.84^{*}$ \\
of controller & $(6.21)$ & $(6.33)$ & $(6.35)$ & $(7.12)$ \\
Financial acquirer & 6.97 & 5.20 & 4.31 & 4.22 \\
& $(7.33)$ & $(7.31)$ & $(7.63)$ & $(8.23)$ \\
R-squared & 0.1819 & 0.1748 & 0.1715 & 0.141 \\
$F$-statistic & 2.76 & 2.73 & 2.52 & 2 \\
$P$-value (Prob $>$ F) & 0.0031 & 0.0034 & 0.0067 & 0.0334 \\
Transactions & 135 & 135 & 135 & 135 \\
\hline
\end{tabular}




\section{TABLE 6 \\ Sensitivity AnALysis \\ Pre- $C N X$ Transactions Only}

Table 6 presents the results of running again the baseline regressions with only the subset of pre-CNX transactions. The dependent variables are the target's CARs over the time windows -30 to $+1,-30$ to $+5,-30$ to +10 , and -30 to +30 trading days relative to the announcement of the transaction. All models are run as ordinary least squares (OLS) with intercept (not reported here) and with heteroskedasticity-consistent standard errors (in parentheses). * significant at $90 \%$ confidence; $* *$ significant at $95 \%$ confidence; $* * *$ significant at $99 \%$ confidence.

\begin{tabular}{lcccc}
\hline \multicolumn{1}{c}{ Variable } & CARs & CARs & CARs & CARs \\
& {$[-30,+1]$} & {$[-30,+5]$} & {$[-30,+10]$} & {$[-30,+30]$} \\
\hline Tender offer $\times$ Post-Cox & $26.52^{*}$ & $28.93^{* *}$ & $28.04^{* *}$ & $33.06^{* *}$ \\
& $(13.37)$ & $(13.44)$ & $(14.06)$ & $(15.50)$ \\
Tender offer & $-18.81^{* *}$ & $-21.12^{* *}$ & $-21.78^{* *}$ & $-23.15^{* *}$ \\
& $(8.27)$ & $(8.71)$ & $(9.39)$ & $(11.47)$ \\
Post-Cox & $-18.40^{*}$ & $-17.79^{*}$ & $-17.43^{*}$ & $-20.26^{*}$ \\
& $(9.82)$ & $(9.80)$ & $(9.92)$ & $(11.45)$ \\
Transaction value (logarithm of the value & $-8.12^{* *}$ & $-8.17^{* *}$ & $-8.39^{* *}$ & $-9.32^{* * *}$ \\
in millions) & $(3.76)$ & $(3.81)$ & $(3.84)$ & $(4.17)$ \\
Stock consideration & $-20.98^{* *}$ & $-21.53^{* * *}$ & $-23.31^{* * *}$ & $-28.86^{* * *}$ \\
& $(7.95)$ & $(8.04)$ & $(8.43)$ & $(10.18)$ \\
Minority approval required $(\%)$ & -0.06 & -0.03 & 0.00 & 0.05 \\
& $(0.16)$ & $(0.16)$ & $(0.17)$ & $(0.20)$ \\
Special committee formation & $19.60^{*}$ & $20.07 *$ & $23.13^{*}$ & $46.39^{* * *}$ \\
& $(10.92)$ & $(10.98)$ & $(11.67)$ & $(17.38)$ \\
Size of the target (logarithm total assets) & 4.39 & 4.84 & 4.42 & 4.32 \\
& $(3.41)$ & $(3.54)$ & $(3.53)$ & $(3.77)$ \\
Pre-deal efficiency (ROA) & 0.01 & 0.04 & 0.09 & 0.19 \\
& $(0.10)$ & $(0.10)$ & $(0.11)$ & $(0.16)$ \\
Public status of controller or parent & 15.61 & 16.50 & 18.55 & $21.93^{*}$ \\
of controller & $(10.62)$ & $(10.64)$ & $(11.20)$ & $(12.68)$ \\
Financial acquirer & -0.12 & -1.40 & 0.18 & 7.73 \\
& $(12.14)$ & $(11.31)$ & $(12.31)$ & $(14.07)$ \\
R-squared & 0.2217 & 0.216 & 0.2133 & 0.2219 \\
$F$-statistic & 1.95 & 1.77 & 1.67 & 2.1 \\
$P$-value (Prob $>$ F) & 0.0463 & 0.0738 & 0.098 & 0.0304 \\
Transactions & 87 & 87 & 87 & 87 \\
\hline
\end{tabular}




\section{TABLE 7 \\ SEnSITIVITy ANALysis \\ Newey-West Adjusted Regressions}

Table 7 presents the results of running the baseline specification with Newey-West standard errors (in parentheses). The dependent variables are the target's CARs over the time windows -30 to $+1,-30$ to $+5,-30$ to +10 , and -30 to +30 trading days relative to the announcement of the transaction. * significant at $90 \%$ confidence; $* *$ significant at $95 \%$ confidence; $* * *$ significant at $99 \%$ confidence.

\begin{tabular}{lcccc}
\hline \multicolumn{1}{c}{ Variable } & CARs & CARs & CARs & CARs \\
& {$[-30,+1]$} & {$[-30,+5]$} & {$[-30,+10]$} & {$[-30,+30]$} \\
\hline Tender offer $\times$ Post-Cox & $27.04^{* *}$ & $29.38^{* * *}$ & $28.51^{* *}$ & $31.85^{* *}$ \\
& $(10.90)$ & $(10.66)$ & $(11.33)$ & $(13.02)$ \\
Tender offer & $-20.30^{* * *}$ & $-21.65 * * *$ & $-21.94^{* * *}$ & $-23.00^{* *}$ \\
& $(7.13)$ & $(7.56)$ & $(8.26)$ & $(9.90)$ \\
Post-Cox & $-18.83^{* *}$ & $-18.93^{* *}$ & $-18.99^{* *}$ & $-21.36^{* *}$ \\
& $(8.22)$ & $(8.16)$ & $(8.30)$ & $(8.94)$ \\
Transaction value (logarithm of the value & $-7.64^{* *}$ & $-7.63 * *$ & $-7.71 * *$ & $-8.35^{*}$ \\
in millions) & $(3.64)$ & $(3.68)$ & $(3.78)$ & $(4.35)$ \\
Stock consideration & $-18.92^{* *}$ & $-18.87^{* *}$ & $-20.92^{* * *}$ & $-25.29^{* * *}$ \\
& $(7.37)$ & $(7.28)$ & $(7.52)$ & $(9.59)$ \\
Minority approval required $(\%)$ & -0.06 & -0.04 & -0.02 & 0.02 \\
& $(0.16)$ & $(0.15)$ & $(0.16)$ & $(0.19)$ \\
Special committee formation & $20.66^{* *}$ & $20.45^{*}$ & $23.05^{*}$ & $45.62^{* *}$ \\
& $(10.33)$ & $(10.59)$ & $(11.80)$ & $(18.27)$ \\
Size of the target (logarithm total assets) & 4.67 & 4.95 & 4.43 & 4.27 \\
& $(3.06)$ & $(3.14)$ & $(3.08)$ & $(3.24)$ \\
Pre-deal efficiency (ROA) & 0.00 & 0.03 & 0.07 & 0.17 \\
& $(0.12)$ & $(0.12)$ & $(0.13)$ & $(0.19)$ \\
Public status of controller or parent & $15.45^{*}$ & $15.25 *$ & $17.24 * *$ & $19.99^{* *}$ \\
of controller & $(7.86)$ & $(7.76)$ & $(8.28)$ & $(9.87)$ \\
Financial acquirer & 1.26 & 0.35 & -0.89 & 3.44 \\
& $(8.06)$ & $(7.32)$ & $(7.92)$ & $(10.73)$ \\
$F$-statistic & 2.26 & 2.1 & 1.68 & 1.91 \\
$P$-value (Prob $>$ F) & 0.0176 & 0.028 & 0.092 & 0.0489 \\
Number of observations & 100 & 100 & 100 & 100 \\
\hline
\end{tabular}




\section{TABLE 8 \\ Sensitivity AnALysis \\ DrisCOLl-KraAy REgRESSIONS}

Table 8 presents the results of running the baseline specification with Discroll-Kraay standard errors (in parentheses). The dependent variables are the target's CARs over the time windows -30 to $+1,-30$ to $+5,-30$ to +10 , and -30 to +30 trading days relative to the announcement of the transaction. * significant at $90 \%$ confidence; $* *$ significant at $95 \%$ confidence; $* * *$ significant at $99 \%$ confidence.

\begin{tabular}{lcccc}
\hline \multicolumn{1}{c}{ Variable } & CARs & CARs & CARs & CARs \\
& {$[-30,+1]$} & {$[-30,+5]$} & {$[-30,+10]$} & {$[-30,+30]$} \\
\hline Tender offer $\times$ Post-Cox & $27.04^{* *}$ & $29.38^{* * *}$ & $28.51^{* *}$ & $31.85^{* *}$ \\
& $(10.82)$ & $(10.59)$ & $(11.27)$ & $(13.07)$ \\
Tender offer & $-20.30^{* * *}$ & $-21.65^{* * *}$ & $-21.94^{* *}$ & $-23.00^{* *}$ \\
& $(7.19)$ & $(7.66)$ & $(8.42)$ & $(10.04)$ \\
Post-Cox & $-18.83^{* *}$ & $-18.93^{* *}$ & $-18.99^{* *}$ & $-21.36^{* *}$ \\
& $(8.54)$ & $(8.50)$ & $(8.51)$ & $(8.84)$ \\
Transaction value (logarithm of the value & $-7.64 * *$ & $-7.63^{* *}$ & $-7.71^{* *}$ & $-8.35^{*}$ \\
in millions) & $(3.64)$ & $(3.71)$ & $(3.82)$ & $(4.44)$ \\
Stock consideration & $-18.92^{* * *}$ & $-18.87^{* * *}$ & $-20.92^{* * *}$ & $-25.29^{* * *}$ \\
& $(7.21)$ & $(7.12)$ & $(7.40)$ & $(9.55)$ \\
Minority approval required $(\%)$ & -0.06 & -0.04 & -0.02 & 0.02 \\
& $(0.15)$ & $(0.14)$ & $(0.15)$ & $(0.18)$ \\
Special committee formation & $20.66 * *$ & $20.45^{*}$ & $23.05^{* *}$ & $45.62^{* *}$ \\
& $(10.24)$ & $(10.60)$ & $(11.41)$ & $(17.90)$ \\
Size of the target (logarithm total assets) & 4.67 & 4.95 & 4.43 & 4.27 \\
& $(3.24)$ & $(3.36)$ & $(3.30)$ & $(3.52)$ \\
Pre-deal efficiency (ROA) & 0.00 & 0.03 & 0.07 & 0.17 \\
& $(0.12)$ & $(0.12)$ & $(0.13)$ & $(0.19)$ \\
Public status of acquirer or parent & $15.45^{*}$ & $15.25^{*}$ & $17.24 *$ & $19.99^{*}$ \\
& $(8.42)$ & $(8.40)$ & $(8.90)$ & $(10.51)$ \\
Financial acquirer & 1.26 & 0.35 & -0.89 & 3.44 \\
& $(8.21)$ & $(7.58)$ & $(8.20)$ & $(11.10)$ \\
R-squared & 0.2071 & 0.2037 & 0.2023 & 0.201 \\
$F$-statistic & 2.37 & 2.24 & 1.74 & 1.95 \\
$P$-value (Prob $>$ F) & 0.0119 & 0.0181 & 0.0754 & 0.0421 \\
Number of observations & 100 & 100 & 100 & 100 \\
\hline
\end{tabular}




\section{TABLE 9 \\ Sensitivity AnAlysis \\ Huber-White Robust Regressions}

Table 9 presents the results of running the baseline specification with Huber-White standard errors (in parentheses). The dependent variables are the target's CARs over the time windows -30 to $+1,-30$ to $+5,-30$ to +10 , and -30 to +30 trading days relative to the announcement of the transaction. * significant at $90 \%$ confidence; $* *$ significant at $95 \%$ confidence; $* * *$ significant at $99 \%$ confidence.

\begin{tabular}{lcccc}
\hline \multicolumn{1}{c}{ Variable } & CARs & CARs & CARs & CARs \\
& {$[-30,+1]$} & {$[-30,+5]$} & {$[-30,+10]$} & {$[-30,+30]$} \\
\hline Tender offer $\times$ Post-Cox & $24.78^{* *}$ & $30.73^{* * *}$ & $26.02^{* *}$ & $28.82^{* * *}$ \\
& $(11.98)$ & $(11.56)$ & $(12.71)$ & $(13.42)$ \\
Tender offer & $-20.29^{* *}$ & $-24.09^{* * *}$ & $-21.95^{* *}$ & $-24.66^{* *}$ \\
& $(9.42)$ & $(9.08)$ & $(9.99)$ & $(10.55)$ \\
Post-Cox & $-15.95^{* *}$ & $-18.90^{* * *}$ & $-16.05^{* *}$ & $-18.57^{* *}$ \\
& $(7.01)$ & $(6.76)$ & $(7.43)$ & $(7.85)$ \\
Transaction value (logarithm of the value & -3.93 & -3.37 & -4.13 & -2.26 \\
in millions) & $(2.67)$ & $(2.58)$ & $(2.84)$ & $(3.00)$ \\
Stock consideration & $-16.67 * *$ & -10.89 & $-19.72 * * *$ & $-13.36^{*}$ \\
& $(6.92)$ & $(6.67)$ & $(7.34)$ & $(7.75)$ \\
Minority approval required $(\%)$ & 0.03 & 0.01 & 0.06 & 0.11 \\
& $(0.12)$ & $(0.12)$ & $(0.13)$ & $(0.13)$ \\
Special committee formation & 12.32 & 13.09 & 15.09 & $34.47 *$ \\
& $(16.40)$ & $(15.81)$ & $(17.39)$ & $(18.37)$ \\
Size of the target (logarithm total assets) & 3.08 & 3.78 & 2.72 & 2.24 \\
& $(2.64)$ & $(2.54)$ & $(2.80)$ & $(2.95)$ \\
Pre-deal efficiency (ROA) & -0.05 & $-0.18 * * *$ & 0.03 & $-0.15^{* *}$ \\
& $(0.06)$ & $(0.06)$ & $(0.07)$ & $(0.07)$ \\
Public status of acquirer or parent & $18.03^{* *}$ & $13.57 * *$ & $20.25 * * *$ & $13.68 *$ \\
& $(7.00)$ & $(6.75)$ & $(7.42)$ & $(7.84)$ \\
Financial acquirer & 10.32 & 5.38 & 6.77 & 6.08 \\
& $(10.57)$ & $(10.19)$ & $(11.21)$ & $(11.84)$ \\
$F$-statistic & 2.04 & 3.15 & 1.86 & 2.31 \\
$P$-value (Prob $>$ F) & 0.0339 & 0.0013 & 0.0553 & 0.0153 \\
Number of observations & 100 & 100 & 100 & 100 \\
\hline
\end{tabular}




\section{TABLE 10 \\ DeAl InCIDENCE}

Table 10 presents the results of regression estimates on the association between the transactional form that controllers choose to execute a freezeout and characteristics of the deal, the controller, and the target. All the specifications are run as logit models, but the results are similar with probit specifications. Because the value of the transaction might be endogenous to the transactional form chosen by the controller, the models are run with and without that independent variable. $*$ significant at $90 \%$ confidence; $* *$ significant at $95 \%$ confidence; $* * *$ significant at $99 \%$ confidence.

\begin{tabular}{|c|c|c|c|c|}
\hline Variable & $\begin{array}{l}\text { Model } 1 \\
\text { All targets }\end{array}$ & $\begin{array}{l}\text { Model } 2 \\
\text { All targets } \\
\text { (including } \\
\text { deal value) }\end{array}$ & $\begin{array}{c}\text { Model } 3 \\
\text { All targets } \\
\text { with minority } \\
\text { vote required }\end{array}$ & $\begin{array}{c}\text { Model } 4 \\
\text { (Minority } \\
\text { vote and deal } \\
\text { value } \\
\text { included) }\end{array}$ \\
\hline Post-Cox & $\begin{array}{l}-0.76 \\
(0.46)\end{array}$ & $\begin{array}{l}-0.76^{*} \\
(0.46)\end{array}$ & $\begin{array}{l}-1.23 * \\
(0.65)\end{array}$ & $\begin{array}{l}-1.40^{*} \\
(0.72)\end{array}$ \\
\hline $\begin{array}{l}\text { Percentage of shares sought in transaction } \\
\text { (natural logarithm) }\end{array}$ & $\begin{array}{l}-0.04 * * \\
(0.02)\end{array}$ & $\begin{array}{l}-0.04 * * \\
(0.02)\end{array}$ & & \\
\hline $\begin{array}{l}\text { Minority shares required to approve } \\
\text { the transaction }\end{array}$ & & & $\begin{array}{c}0.12 * * * \\
(0.03)\end{array}$ & $\begin{array}{c}0.14 * * * \\
(0.03)\end{array}$ \\
\hline Deal value (natural logarithm) & & $\begin{array}{c}0.12 \\
(0.19)\end{array}$ & & $\begin{array}{c}-0.90^{* *} \\
(0.36)\end{array}$ \\
\hline Stock consideration & $\begin{array}{l}-0.08 \\
(0.53)\end{array}$ & $\begin{array}{l}-0.19 \\
(0.54)\end{array}$ & $\begin{array}{c}0.65 \\
(0.78)\end{array}$ & $\begin{array}{c}1.02 \\
(0.83)\end{array}$ \\
\hline Total assets (natural logarithm) & $\begin{array}{l}0.32 * * \\
(0.11)\end{array}$ & $\begin{array}{c}0.21 \\
(0.20)\end{array}$ & $\begin{array}{l}0.33^{*} \\
(0.18)\end{array}$ & $\begin{array}{l}1.15^{* * * *} \\
(0.40)\end{array}$ \\
\hline Pre-deal efficiency (ROA) & $\begin{array}{c}0.00 \\
(0.00)\end{array}$ & $\begin{array}{c}0.00 \\
(0.00)\end{array}$ & $\begin{array}{c}0.00 \\
(0.01)\end{array}$ & $\begin{array}{c}0.01 \\
(0.01)\end{array}$ \\
\hline Public status of acquirer or parent & $\begin{array}{c}0.40 \\
(0.51)\end{array}$ & $\begin{array}{c}0.41 \\
(0.54)\end{array}$ & $\begin{array}{c}0.29 \\
(0.70)\end{array}$ & $\begin{array}{l}1.19 \\
(0.84)\end{array}$ \\
\hline Financial acquirer & $\begin{array}{c}0.38 \\
(0.75)\end{array}$ & $\begin{array}{c}0.60 \\
(0.78)\end{array}$ & $\begin{array}{c}0.90 \\
(1.05)\end{array}$ & $\begin{array}{c}1.49 \\
(1.21)\end{array}$ \\
\hline Pseudo R-squared & 0.1322 & 0.1395 & 0.546 & 0.5969 \\
\hline LR chi2 & 21.62 & 22.72 & 88.62 & 96.52 \\
\hline Prob $>$ chi 2 & 0.003 & 0.0037 & 0 & 0 \\
\hline Number of observations & 143 & 142 & 141 & 140 \\
\hline
\end{tabular}

